\title{
Analysis of Effectiveness of Lean Management in Improvement of Service in Installation Nutrition RSUD dr. Iskak Tulungagung
}

\author{
Ida Srijani ${ }^{1}$ \\ ${ }^{1}$ Magister of Health Study \\ Program of STIKes Surya Mitra \\ Husada Kediri \\ idasriyani@gmail.com
}

Received : January 25, 2018

Accepted : May 08, 2018

Published : May 11, 2018

\begin{abstract}
Quality of nutrition instalation service is determined from four processes; food planning, food preparation, food preparation, food processing and food distribution to patients. Efforts to improve service quality are modified processes using LEAN management. Pre experimental research design with one group pretest - post test design. Sample 36 people from all nutrition installation officer of food management system (MSPM) with sampling technique Non probability sampling type purposive sampling. The results of the research shows the influence of LEAN management implementation to the aspect of meal planning before and after intervention with wilcoxon test $(\mathrm{p}=0,083)$ with pretest value $100 \%$ good quality. In the aspect of foodstuff processing obtained wilcoxon test $(\mathrm{p}=0,001)$ with pre test value $100 \%$ enough quality and post test value $100 \%$ quality is sufficient and the post test value is $21 \%$, the remaining quality is $79 \%$ good quality.
\end{abstract}

Keywords : LEAN management, Quality of nutrition installation service.

Copyright $\odot 2018$ STIKes Surya Mitra Husada

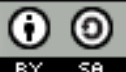

This is an open-acces article distributed under the terms of the Creative Commons Attribution-ShareAlike 4.0 International License. 


\section{INTRODUCTION}

The organization of hospital food is a series of activities ranging from food planning, food storage preparation and food distribution to consumers in this case is hospital patients, to achieve optimal health status through proper administration (MOH RI, 2013). The organization of hospital food is carried out with the aim that the treated patients can obtain food that suits their nutritional needs and can accelerate the healing of the disease. Four such processes must run maximally to provide maximum service to the patient Many problems that can occur from the four processes such as the standard menu of patients has not been appropriate guideline criteria, food process planning process has not been maximized, the process of ordering food items that have not complied with the guidelines, the acceptance of materials is not done cleaning process on all materials that come, well documented, warehouse storage has not met the standard food warehouse, there is no matching cutting of food with portion standard, cooking process not yet fully in accordance with standard of recipe made, process of quality control not yet running maximal, process pemorian still long and involving many officer, frequent errors in the feeding of feeding, the communication has not been effective with the patient.

LEAN management is one method to reduce the problems that occur so as to improve the quality of nutrition installation services to patients. With some LEAN method used is kanban; instructions on when it is time to order goods, from whom and how much, by teaching MSPM officers: conveyor belt techniques, patient fooding techniques, patient turnover techniques, menu planning techniques and groceries, food procurement techniques. Visual management; a set of tools that can explain the rules and others briefly, by making labels on clean and dirty dining trolleys, cooking utensils, warehouse locations and marking on grocery shelves in warehouses. Learning organization; a form of continuous improvement aimed at eliminating waste that brings losses or does not bring value at all, by teaching prepost conference techniques of Nutrition installations. $5 \mathrm{~S}$; methods to make the workplace orderly so that all the items can be found easily (seiri: resik, seiketsu: rawat, sitsuke: diligent), by teaching hygiene tools, cleanliness of trains, storage techniques in the warehouse . Error proofing; a device of methods used in preventing defects that work automatically and inexpensively, by labeling identities and computerized patient menus. Re-layouting, changing the design of kitchen space to the standard. Re-engineering, add, modify or reduce existing tool.

\section{METHOD}

This research design uses experimental pre with one group pretest approach - post test design. Sample of 36 people from all officers of nutrition installation of food management system (MSPM) by using sampling technique Non probability sampling type purposive sampling. Independent variable of research is LEAN management. Dependent variable is the quality of service delivery system of the patient in the nutrient installation. Data were collected by using checlist, then data coded and analyzed using wilcoxon statistic test.

\section{RESULTS}

The research data is divided into 4 aspects: food planning, storage and storage, food processing, and food distribution. maximum answer on the questionnaire. Data from pre test and post test is done coding then done different test with wilcoxon. 
a. $\quad$ Food planning

Table 2.1 Value of Pre Test And Post Test Food Planning And Wilcoxon Test Value

\begin{tabular}{cccc}
\hline \multirow{2}{*}{ No Respondent } & \multicolumn{3}{c}{ Quality of Nutrition Service } \\
\cline { 2 - 4 } & \multicolumn{3}{c}{ Food planning } \\
\cline { 2 - 4 } & pre test & post test & Trend \\
\hline 1 & 56 & 83 & $48,21 \%$ \\
\hline 2 & 56 & 83 & $48,21 \%$ \\
\hline 3 & 56 & 83 & $48,21 \%$ \\
\hline Wilcoxon test & Average & & $48,21 \%$ \\
\hline
\end{tabular}

Based on the results of the research in the above table it is known that the quality of nutritional services on the aspects of "food planning" pre and post test in get an average quality improvement of $48.21 \%$, then tested Wilcoxon statistics to determine the difference between pre and post intervention, 0.083, it can be concluded that there is no significant difference between pre and post intervention, at $95 \%$ confidence level. The difference between positive trend and wilcoxon test can occur due to several factors such as the number of samples that only 3 respondents, and the data samples are normally distributed.

b. Reception, preparation and storage of groceries

Table 2.2 Value of Pre Test And Post Test Reception, Preparation And Storage Of Food And Wilcoxon Test Value

\begin{tabular}{cccc}
\hline \multirow{2}{*}{ No Respondent } & \multicolumn{3}{c}{ Quality of Nutrition Service } \\
\cline { 2 - 4 } & \multicolumn{3}{c}{ Reception, preparation and storage of food } \\
\cline { 2 - 4 } & pre test & post test & Trend \\
\hline 1 & 42 & 61 & $45,24 \%$ \\
\hline 2 & 38 & 56 & $47,37 \%$ \\
\hline Wilcoxon test & Average & $\mathrm{p}=0,157$ & $46,31 \%$ \\
\hline
\end{tabular}

Based on the results of research in the above table it is known that the quality of nutrition services on the aspects of "Acceptance, Preparation And Storage Food" pre and post test in get an average quality improvement of $46.31 \%$, then tested Wilcoxon statistics to determine the difference pre and post intervention, obtained indigo $\mathrm{p}=0,157$, which can be concluded that there is no significant difference between pre and post intervention, at $95 \%$ confidence level. The difference between positive trend and wilcoxon test can occur due to several factors such as the number of samples that only 3 respondents, and the data samples are normally distributed. 
c. Food processing

Table 2.3 Preliminary values and post test food processing and wilcoxon test scores

\begin{tabular}{cccc}
\hline \multirow{2}{*}{ No Respondent } & \multicolumn{3}{c}{ Quality of Nutrition Service } \\
\cline { 2 - 4 } & \multicolumn{3}{c}{ food processing } \\
\cline { 2 - 4 } & pre test & post test & Trend \\
\hline 1 & 32 & 55 & $71,88 \%$ \\
\hline 2 & 41 & 51 & $24,39 \%$ \\
\hline 3 & 35 & 51 & $45,71 \%$ \\
\hline 4 & 35 & 54 & $54,29 \%$ \\
\hline 5 & 35 & 58 & $65,71 \%$ \\
\hline 6 & 35 & 51 & $45,71 \%$ \\
\hline 7 & 35 & 54 & $54,29 \%$ \\
\hline 8 & 34 & 57 & $67,65 \%$ \\
\hline 9 & 36 & 55 & $52,78 \%$ \\
\hline 10 & 38 & 58 & $52,63 \%$ \\
\hline 11 & 33 & 56 & $69,70 \%$ \\
\hline 12 & 30 & 54 & $50,00 \%$ \\
\hline Wilcoxon test & Average & $\mathrm{p}=0,083$ & \\
\hline
\end{tabular}

Based on the results of the research in the table above it is known that the quality of nutritional services on the aspects of "food processing" pre and post test in get an average quality improvement of $57.06 \%$, with the largest increase of $80 \%$ and the smallest $24.39 \%$ then tested statistical Wilcoxon to know the difference of pre and post intervention, got indigo $\mathrm{p}=0,001$, which can be concluded that there is a significant difference between pre and post intervention, at $95 \%$ confidence level.

\section{d. Food distribution}

Table 2.4 The pre test and post test values of food distribution and wilcoxon test values

\begin{tabular}{|c|c|c|c|}
\hline \multirow{3}{*}{ No Responden } & \multicolumn{3}{|c|}{ Quality of Nutrition Service } \\
\hline & \multicolumn{3}{|c|}{ food distribution } \\
\hline & pre test & post test & Trend \\
\hline 1 & 41 & 66 & $60,98 \%$ \\
\hline 2 & 42 & 61 & $45,24 \%$ \\
\hline 3 & 40 & 60 & $50,00 \%$ \\
\hline 4 & 42 & 55 & $30,95 \%$ \\
\hline 5 & 40 & 59 & $47,50 \%$ \\
\hline 6 & 44 & 60 & $36,36 \%$ \\
\hline 7 & 42 & 61 & $45,24 \%$ \\
\hline 8 & 45 & 61 & $35,36 \%$ \\
\hline 9 & 41 & 60 & $46,34 \%$ \\
\hline 10 & 38 & 61 & $60,53 \%$ \\
\hline 11 & 33 & 55 & $66,67 \%$ \\
\hline 12 & 35 & 60 & $71,43 \%$ \\
\hline 13 & 41 & 54 & $31,71 \%$ \\
\hline 14 & 40 & 60 & $50,00 \%$ \\
\hline 15 & 37 & 49 & $32,43 \%$ \\
\hline 16 & 38 & 49 & $28,95 \%$ \\
\hline
\end{tabular}


Quality of Nutrition Service

\begin{tabular}{cccc}
\cline { 2 - 4 } No Responden & \multicolumn{3}{c}{ food distribution } \\
\cline { 2 - 4 } & pre test & post test & Trend \\
\hline 17 & 39 & 58 & $48,72 \%$ \\
\hline 18 & 43 & 50 & $16,28 \%$ \\
\hline 19 & 37 & 44 & $18,92 \%$ \\
\hline Test Wilcoxon & Average & & $43,36 \%$ \\
\hline
\end{tabular}

Based on the results of research in the above table it is known that the quality of nutritional services on the aspect of "food distribution" pre and post test in get an average quality improvement of $43.36 \%$, with the largest increase of $71.42 \%$ and the smallest $16.28 \%$ Wilcoxon to know the difference of pre and post intervention, got $\mathrm{p}$ value $=0.000$, which can be concluded that there is significant difference between pre and post intervention, at $95 \%$ confidence level.

\section{DISCUSSION}

a. The Influence of Food Planning Before and After The Implementation Of LEAN Management To The Feeding System Of Nutrition Installation Of Dr. Iskak Tulungagung Hospital.

Standard in the Hospital Nutrition Services Guidebook, Ministry of Health, in 2013, explained that the planning in the implementation of food in nutrient installations is divided into 2, namely: Standard planning menu and Food Planning.

The process of planning the implementation of food in nutrient installations has not been fully in accordance with the standards / guidelines. There are some activities that have not been implemented among others: the standard menu of patients has not been in accordance with guideline criteria, food planning process has not been maximized, planning still impressed seporadic and not based on precise calculation techniques and found excessive food inventory in nutrition warehouse at risk of food damage. Then also found the process of ordering / procurement of food that has not been according to the guidelines. Procurement is done manually by phone, or SMS or WA (whatsApp) without any documentation of clear administrative documentation of order type data, quantity and specifications. So that there will be difficulties in the evaluation of the quality of goods that come.

LEAN intervention is then granted in the process of food planning by using one of the LEAN method is the method of KANBAN is a clue about when it is time to order goods, from whom and how much, by teaching to MSPM officers in the form of techniques for making fooding patients, patient turnover techniques, menu planning and patient foodstuffs and food procurement techniques in the form of standard operational procedures (SPO). SPO that has been made is done socialization to the relevant officers so that officers can understand and implement.

b. The Effect of Acceptance, Preparation And Storage Of Food Before And After The Implementation Of Manajemaenn LEAN In The System Of Nutrition Installation Installation Of Dr Iskak Hospital Tulungagung.

In the process Acceptance of foodstuffs carried out various activities ranging from food received dipriksa whether it is in accordance with the specified specifications and then store food in accordance with the type of food or processed directly. Storage of foodstuffs should be separated between dry and wet ingredients, the ingredients that should be stored in the refrigerator after cleaning should be stored in the refrigerator immediately, then the dry material can be stored in the warehouse with a standard warehouse storage system. For the 
distribution of food must be accompanied by a receipt and recorded in the book stock of each material.

The process of preparation of foodstuffs for the processed, done in accordance with the standard menu, standard recipes and seasonings by washing, cutting, juice, dispensing and so forth according to standard procedures (Hospital Nutrition Services Manual, Kemeterian Health, 2013).

Based on the observations of the researchers, the process of receiving, preparing and storing food in nutrient installations has not been fully consistent with these standards / guidelines. There are some activities that have not been implemented including: the acceptance of materials is not done the cleaning process on all materials that come, the order list material is not well documented so that difficulty to evaluate the material coming, storage warehouse not yet meet the standard warehouse material with standard card stock materials and out, food stuff cards, FIFO and FEFO principles, a minimum of $15 \mathrm{~m}$ buffer racks. In the preparation process found the preparation of spices that have been so / half so stored for too long, there has been no matching cuts of food with standard portion.

The LEAN method of intervention in the process of acceptance, preparation and storage of food using LEAN method is the method of KANBAN is a guide on when it is time to order goods, from whom and how much, by teaching MSPM officers in the form of food procurement techniques made in the form of operational standards procedure (SPO). SPO that has been made is done socialization to the relevant officers so that officers can understand and implement. Then the Visual Management method, is a set of tools that can explain the rules and others briefly, with the labeling on the shelves in the warehouse according to the classification of materials and equipped with stock card materials.

Then the method of re-layouting is to change the design space in the kitchen, by changing the position of warehouse storage shelves to fit the standard, the position where the receipt of materials. Then re-engineering is to add, change or reduce existing tool resources by adding some pallets as a basic foodstuff with a minimum height of $15 \mathrm{~cm}$, adding cookware storage racks equipped with UV (ultra violet) rays to kill germs, adding the number of trolleys / carts, both clean trains (delivering food and snacks) as well as dirty trains (picking up patient's feeding utensils).

c. Effect Of Food Processing Before And After Implementation Of LEAN Management Installed Nutrition Of RSUD Dr. Iskak Tulungagung.

Food processing is an activity to convert (cook) raw materials into ingredients that are ready to eat, quality, and safe for consumption. The purpose of processing (cooking) is: improving digestibility, improving and maintaining the color, taste, tenderness and appearance of food, free of organisms and harmful substances to the body. The cooking process uses various methods: cooking with air medium, cooking with water medium, cooking using fat, cooking through pan wall, cooking with combination, cooking with electromagnetic. Prerequisites prior to cooking are: the availability of menu standards, menu cycles, prescription standards, availability of foodstuffs, availability of cooking equipment, availability of rules in the quality of controls, availability of fixed cooking procedures, availability of regulations on the use of food additives (BTP). Hospital, Kemeterian Kesehatan, 2013).

Based on the observations of the researchers, the process of receiving, preparing and storing food in nutrient installations has not been fully consistent with these standards / guidelines. There are some activities that have not been implemented include: cooking of some materials then stored in the refrigerator over standard time, the process of pemaskan not fully in accordance with the standard recipe made, the process of quality control has not run optimally, the process of pemorsian is still long and involving many officers, feeding.

LEAN interventions are then granted in the process of processing food by using the LEAN method is the method of KANBAN is a guide on when it is time to order goods, from whom and how much, by applying a conveyor belt technique. Then the method of Error proofing, is a device that method used in preventing defects that work automatically and 
inexpensively, with the technique of labeling identities and computerized patient menus. Then the method of re-layouting is to change the design space in the kitchen, by separating the kitchen cake and non cooking kitchen. Then re-engineering is to add, change or reduce existing equipment resources by adding ekhaus fan, increasing the number of highpressure stoves, adding steam steam engine for cooking.

d. Effect of Patient's Food Distribution Before And After The Implementation Of LEAN Management In Nutrition Installation Of RSUD Dr. ISKAK Tulungagung.

Food distribution process is a series of food delivery activities in accordance with the type of food and the number of servings of consumers / patients served. With prerequisites: the availability of portion standards, the existence of food collection regulations, the list of food demand for patients, the existence of standard distribution equipment.

Distribution has 3 systems: centralized system, non-centralized system and centralized and unified centralized system. (Hospital Nutrition Service Manual, Ministry of Health, 2013) Based on the observations of researchers, the process of food distribution in nutrient installations has not been fully in accordance with the standards / guidelines. There are some activities that have not been implemented include: the completeness of the distribution tools (dirty trolley and clean), the communication has not been effective, cleanliness and arrangement of trolleys that have not been awake, the cleaning of cutlery that has not been standard.

LEAN management intervention is then given in the process of processing food using LEAN method 5S method, is a method to make the workplace become organized so that all goods can be found easily (seiri: concise, seiton: neat, seiso: resik, seiketsu: care, sitsuke: diligent), by teaching the technique of cleanliness tool, cleanliness of the train, the technique of storing goods in the tool warehouse.

\section{CONCLUSION}

The quality of nutrition service installation of RSUD Dr. Iskak Tulungagung after the implementation of LEAN management has improved quality in four aspects of food implementation, ie food planning, food storage, food preparation, food processing and food distribution.

\section{RESULTS}

a. In the aspect of food planning and aspects of reception, preparation and storage of food at the nutrition installation of RSUD Dr. Iskak. The hospital needs to make an integrated computerized information management system with inpatient unit, hospital procurement unit and other related units to simplify the process of planning of foodstuff, ordering of foodstuff, acceptance of foodstuff, management of foodstuffs and ordering of patient's diet. The information system can use or modify SIMRS (Hospital Management Information System) that already exist in the hospital.

b. The Hospital conducts periodic internal evaluations of the patient's feeding service at nutritional installations.

\section{REFERENCES}

Departemen Kesehatan Republik Indonesia. (2004). Keputusan Menteri Kesehatan Republik Indonesia Nomor 1204/MENKES/SK/X/2004. 2004. Persyaratan Kesehatan Lingkungan Rumah Sakit. Jakarta : Depkes RI.

Departemen Kesehatan Republik Indonesia. (2004). Kepmenkes No : 715/Menkes/SK/V/2004. Persyaratan Hygiene Sanitasi Jasaboga, Jakarta : Depkes RI. 
Departemen Kesehatan Republik Indonesia. (2013). Pedoman Pelayanan Gizi di Rumah Sakit. Jakarta : Depkes RI.

Drs. Moch. Imron TA, MM, MBA. (2009). Manajemen Logistik Rumah Sakit Azrul. Azwar. 2012. Pengantar Aministrasi dan Manajemen Kesehatan. Jakarta : Binarupa Aksara.

Firman. (2015). https://manajemenrumahsakit.net/2017/02/kunci-sukses-implementasi-leanmanagement-di-rumah-sakit/. Diakses pada 17 Oktober 2017 pukul 19.00 WIB.

Gaspersz, \& Vincent. (2007). Lean Six Sigma for Manufacturing and Services Industries. Jakarta: Gramedia Pustaka Utama.

Guwandi. (2011). Mutu dan Pelayanan Rumah Sakit. Jakarta : Rineka Cipta.

Hendartini et al. (2016). http://kanalpengetahuan.fk.ugm.ac.id/kunci-sukses-implementasilean-management-di-rumah-sakit/. Diakses pada 16 Oktober 2017 pukul 19.00 WIB.

Imron, \& Moch. (2009). Manajemen Logistik Rumah Sakit. Jakarta : Sagung Seto Sugiyono. 2011. Metode Penelitian Kuantitatif, Kualitatif dan R\&D. Bandung : Alfabeta.

Irawan, \& Sony DR. (2004). The toyota way-Jeffrey K, Liker. Jakarta : PQM konsultan.

Kementerian Kesehatan RI. Pusat Sarana dan Prasarana dan Peralatan Kesehatan. (2010). Sesi Perencanaan, Pedoman Teknis Sarana dan Prasarana Rumah Sakit Kelas B. Jakarta : Depkes RI.

Keputusan Menteri Kesehatan Republik Indonesia Nomor 983/Menkes/SK/XI/1992. (1992). Pedoman Organisasi Rumah Sakit. Jakarta : Depkes RI.

Nursalam \& Siti Pariani. (2010). Riset Keperawatan. Jakarta : Salemba Medika.

Nursalam. (2010). Konsep dan Penerapan Metodologi Penelitian Ilmu Keperawatan. Jakarta : Salemba Medika.

N.N. (2017). Lean Hospital-Lean Rumah Sakit (1). Diakses pada 2 Oktober 2017 Pukul 14.39 WIB.

Undang - Undang Nomor 44 tahun (2009). 2009. Publikasi Undang - Undang Nomor 44 tahun 2009 tentang Rumah Sakit. Jakarta : Depkes RI. 